\title{
Perancangan dan Pengembangan Toko Online dengan Metode Interaction Flow Modeling Language (Studi Kasus Toko Winata)
}

\author{
Steven Putera Suryanto \\ Program Studi Sistem Informasi \\ Institut Informatika Indonesia \\ bos2tep@gmail.com
}

\author{
Timothy John Pattiasina \\ Program Studi Sistem Informasi \\ Institut Informatika Indonesia \\ temmy@ikado.ac.id
}

\author{
Anggya Soetarmono \\ Program Studi Sistem Informasi \\ Institut Informatika Indonesia \\ anggya@ikado.ac.id
}

\begin{abstract}
Abstrak-Penjualan produk dan interaksi dengan konsumen adalah proses yang sering dilakukan di usaha/toko yang bergerak di bidang penjualan. Proses penjualan biasanya dilakukan secara langsung dan bertatap muka dengan konsumen. Persoalan penjualan secara langsung berkaitan dengan ruang lingkup dan waktu yang terbatas. Pada penelitian ini penulis merancang dan mengembangkan toko online dengan studi kasus Toko Winata dan menggunakan metode Interaction Flow Modeling Language (IFML). Fungsi dari metode IFML adalah membantu mempermudah komunikasi desain interaksi dengan pemangku kepentingan non-teknis. Fokus penelitian ini adalah pada tampilan antar muka yang menarik, kemudahan penggunaan, serta penyampaian informasi produk kepada konsumen dengan memanfaatkan website sebagai salah satu layanan secara online. Penelitian ini akan membahas mengenai penjualan produk dan interaksi dengan konsumen secara online. Dengan adanya toko online ini diharapkan dapat memberikan peningkatan pendapatan pada Toko Winata dan keuntungan berupa ruang lingkup yang lebih luas dan waktu yang banyak sehingga dapat menjawab persoalan penjualan secara langsung

Kata Kunci : Penjualan, Konsumen, Toko Online, Toko Winata, IFML.
\end{abstract}

\section{PENDAHULUAN}

Teknologi menurut Kamus Besar Bahasa Indonesia (KBBI) adalah keseluruhan sarana untuk menyediakan barang-barang yang diperlukan bagi kelangsungan dan kenyamanan hidup manusia. Pada era modern saat ini teknologi bukan merupakan hal yang asing, hampir sebagian besar manusia yang hidup di perkotaan khususnya fasih dalam penggunaan teknologi. Teknologi memiliki cakupan yang luas salah satunya adalah penerapan dalam bidang ekonomi yang dapat menunjang produktivitas suatu usaha, namun dalam penerapannya tidak berjalan secepat perkembangan teknologi itu sendiri. Salah satu perkembangan terknologi yang berdampak besar adalah internet.
Internet merupakan hal yang penting saat ini karena memiliki ruang lingkup yang luas tanpa ada batasan. Ketergantungan masyarakat yang hidup di perkotaan khususnya terhadap internet begitu besar, bahkan sekarang internet bisa dikelompokkan sebagai kebutuhan primer bagi sebagian orang. Pengaruh dan ruang lingkup yang besar membuat internet menjadi sasaran empuk dalam mencari keuntungan, salah satunya adalah $e$-commerce.

Electronic commerce atau biasa disebut e-commerce adalah penggunaan media transmisi elektronik untuk terlibat dalam pertukaran, termasuk pembelian dan penjualan dari produk dan jasa yang membutuhkan transportasi, baik secara fisik maupun digital dari satu lokasi ke lokasi lain. Ecommerce merupakan salah satu bagian dari e-business namun memiliki ruang lingkup yang lebih sempit. Di Indonesia pangsa pasar e-commerce sangat besar. Semakin banyak e-commerce (layanan untuk sarana jual/beli online) yang berkembang di Indonesia membuat banyak perubahan pola belanja masyarakat yang awal bersifat konvensional kini berbelanja cukup dengan memilih produk yang ada di web/blog.

Hal inilah yang mendasari pemilik Toko Winata ingin mengembangkan usahanya, dimana sampai saat ini Toko Winata masih menggunakan metode konvensional dalam pemasaran dan penjualan produk-produknya. Meskipun usaha yang sekarang dilakukan dengan metode konvensional berjalan cukup baik, namun pemilik merasa perlu adanya inovasi agar dapat mengembangkan usahanya menjadi lebih baik serta dapat menyesuaikan dengan perkembangan zaman. Hal berikutnya yang mendasari dibuatnya website tersebut disebabkan karena sudah dimilikinya aplikasi sistem informasi persediaan barang berbasis web pada toko tersebut, sehingga pengembangan kearah toko online dirasa akan cukup mudah untuk dilakukan.

Perancangan dan pembuatan website toko online ini akan menggunakan metode Interaction Flow Modeling Language (IFML). Pemilihan metode ini dipakai oleh penulis dikarenakan masih sedikitnya pengembangan sistem yang menggunakan metode IFML dalam pembuatannya, sehingga mendorong penulis untuk mengembangkan penelitian dengan memanfaatkan metode tersebut, disamping kelebihan dari metode ini dalam mendukung mengekspresikan konten, 
interaksi pengguna, dan mengatur perilaku dari front-end aplikasi perangkat lunak.

\section{METODOLOGI PENELITIAN}

\section{A. Sistem Informasi}

Sistem Informasi terdiri dari dua kata yaitu sistem dan informasi. Pengertian sistem adalah suatu jaringan kerja dari prosedur-prosedur yang saling berhubungan, berkumpul bersama-sama untuk melakukan suatu kegiatan atau menyelesaikan suatu sasaran tertentu. Informasi adalah data yang telah diproses menjadi bentuk yang memiliki arti bagi penerima dan dapat berupa fakta, suatu nilai yang bermanfaat. Sistem informasi adalah sekelompok elemen-elemen yang terintegrasi dengan tujuan yang sama untuk mencapai tujuan. Sistem juga merupakan suatu jaringan kerja dari prosedurprosedur yang saling berhubungan, terkumpul bersama-sama untuk melakukan suatu kegiatan atau untuk tujuan tertentu.

\section{B. Basis Data}

Sistem basis data adalah sistem terkomputerisasi yang tujuan utamanya adalah memelihara data yang sudah diolah atau informasi dan membuat informasi tersedia saat dibutuhkan [1]. Pada intinya basis data adalah media untuk menyimpan data agar dapat diakses dengan mudah dan cepat. Sistem informasi tidak dapat dipisahkan dengan kebutuhan akan basis data apapun bentuknya, entah berupa file teks ataupun Database Management System (DBMS).

\section{Database Management System (DBMS)}

DBMS (Database Management System) atau dalam bahasa Indonesia sering disebut sebagai Sistem Manajemen Basis Data adalah suatu sistem aplikasi yang digunakan untuk menyimpan, mengelola, dan menampilkan data. Karena pentingnya data bagi suatu organisasi atau perusahaan, maka hampir sebagian besar perusahaan memanfaatkan DBMS alam mengelola data yang mereka miliki. Pengelolaan DBMS sendiri biasanya ditangani oleh tenaga ahli yang spesialis menangani DBMS yang disebut sebagai DBA (Database Administrator). Hampir semua DBMS mengapdosi SQL sebagai bahasa untuk mengelola data pada DBMS.

\section{Electronic Commerce (E-Commerce)}

E-commerce memiliki 4 definisi yang berbeda yaitu [2]:

- Dari perspektif komunikasi, e-commerce adalah penyampaian informasi, produk/jasa, atau pembayaran melalui saluran telepon, jaringan komputer.

- Dari perspektif proses bisnis, e-commerce adalah aplikasi teknologi menuju otomatisasi transaksi bisnis dan alur kerja.

- Dari perspektif layanan, e-commerce adalah alat untuk membahas keinginan perusahaan, konsumen, dan manajemen untuk memangkas biaya layanan, sementara meningkatkan kualitas barang dan meningkatkan kecepatan pelayanan.
- Dari perspektif online, e-commerce menyediakan kemampuan membeli dan menjual produk dan informasi di internet dan layanan online lainnya.

\section{E. Interaction Flow Modeling Language (IFML)}

IFML (Interaction Flow Modeling Language) adalah bahasa pemodelan yang sangat terinspirasi oleh WebML dan mewakili generalisasi dari domain web untuk aplikasi generic pemodelan front-end [3]. IFML dirancang untuk mengekspresikan konten, interaksi pengguna, dan mengatur perilaku dari front-end aplikasi perangkat lunak. IFML terinspirasi dari pengalaman panjang 10 tahun WebML dan WebRatio dan telah diadopsi sebagai standar oleh OMG (Object Management Group) pada Maret 2013. Tujuan bahasa pemodelan ini untuk mengekspresikan:

- Visualisasi konten dalam antar muka pengguna

- Jalur navigasi

- Interaksi dan event pengguna

- Mengikat pada logika bisnis

- Mengikat pada persistence layer dari beragam domain pada aplikasi front-end.

Keuntungan yang dimiliki dari penerapan metode ini adalah:

- $\quad$ Perspektif yang berbeda dari spesifikasi formal pada front-end.

- Memisahkan masalah implementasi khusus dari antar muka pengguna.

- Pemisahan perhatian interaksi pengguna dengan backend.

- Memungkinkan komunikasi desain interaksi kepada pemangku kepentingan non-teknis.

- Kode generasi otomatis juga merupakan bagian dari aplikasi front-end.

Berikut ini contoh notasi IFML beserta dengan keterangannya:

Tabel 1. Notasi IFML

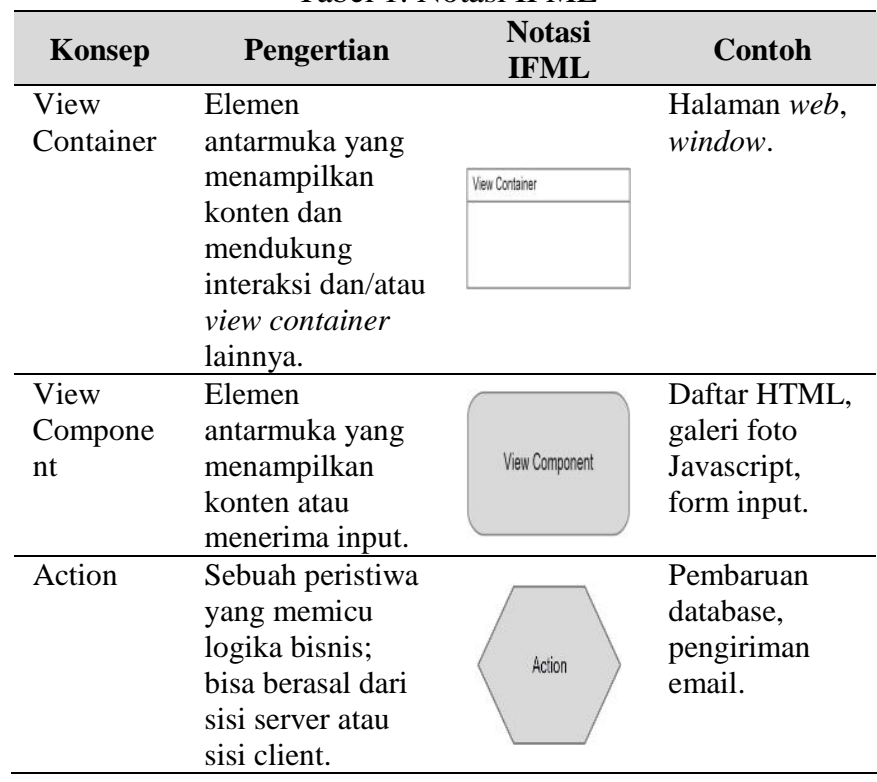


Tabel 1. Notasi IFML (Lanjutan)

\begin{tabular}{|c|c|c|c|}
\hline Konsep & Pengertian & Notasi IFML & Contoh \\
\hline $\begin{array}{l}\text { Navigatio } \\
\text { n Flow }\end{array}$ & $\begin{array}{l}\text { Ketergantungan } \\
\text { input-output. } \\
\text { Sumber link } \\
\text { memiliki } \\
\text { beberapa output } \\
\text { yang berhubungan } \\
\text { dengan input dari } \\
\text { target link. }\end{array}$ & & $\begin{array}{l}\text { Mengirim } \\
\text { dan } \\
\text { menerima } \\
\text { parameter } \\
\text { atas } \\
\text { permintaan } \\
\text { HTTP. }\end{array}$ \\
\hline Data Flow & $\begin{array}{l}\text { Data yang lewat } \\
\text { di antara view } \\
\text { components atau } \\
\text { action sebagai } \\
\text { akibat interaksi } \\
\text { pengguna } \\
\text { sebelumnya. }\end{array}$ & & $\begin{array}{l}\text { Mentransfer } \\
\text { jumlah } \\
\text { pembelian } \\
\text { dalam } \\
\text { keranjang } \\
\text { belanja } \\
\text { untuk } \\
\text { melakukan } \\
\text { pembayaran } \\
\text {. }\end{array}$ \\
\hline Event & $\begin{array}{l}\text { Kejadian yang } \\
\text { mempengaruhi } \\
\text { keadaan aplikasi. }\end{array}$ & & \\
\hline $\begin{array}{l}\text { Parameter } \\
\text { binding }\end{array}$ & $\begin{array}{l}\text { Spesifikasi yang } \\
\text { merupakan } \\
\text { parameter input } \\
\text { dari sumber } \\
\text { dikaitkan dengan } \\
\text { target yaitu } \\
\text { parameter output. }\end{array}$ & $\begin{array}{l}\text { From } \rightarrow \text { To } \\
\text { From } \rightarrow \text { To }\end{array}$ & $\begin{array}{l}\text { Menghubun } \\
\text { gkan judul } \\
\text { album dan } \\
\text { tahun album } \\
\text { yang } \\
\text { dimasukkan } \\
\text { dari } \\
\text { komponen } \\
\text { ke } \\
\text { parameter } \\
\text { input } \\
\text { komponen } \\
\text { lain }\end{array}$ \\
\hline
\end{tabular}

\section{F. MySQL}

MySQL adalah sebuah perangkat lunak sistem manajemen basis data SQL (DBMS) yang multithread dan multi-user [4]. MySQL dibuat oleh TcX dan telah dipercaya mengelola sistem dengan 40 buah database berisi 10.000 tabel dan 500 diantaranya memiliki 7 juta baris. MySQL AB merupakan perusahaan komersial Swedia yang mensponsori dan yang memiliki MySQL. Pendiri MySQL AB adalah dua orang Swedia yang bernama David Axmark dan Allan Larsson serta satu orang Finlandia bernama Michael Monty.

Setiap pengguna MySQL dapat menggunakannya secara bebas yang didistribusikan gratis dibawah lisensi GPL (General Public License) namun tidak boleh menjadikan produk turunan yang bersifat komersial. Pada saat ini MySQL merupakan database server yang sangat terkenal di dunia karena bahasa dasar yang digunakan untuk mengakses database yaitu Structured Query Language (SQL).

\section{G. Adobe Dreamweaver}

Adobe Dreamweaver adalah aplikasi yang digunakan untuk keperluan editor HTML, CSS, PHP, Javascript dan lain-lain [5]. Aplikasi ini sering digunakan para pengembang web untuk membantu dalam membuat berbagai template untuk blog dan web termasuk elemen-elemen di dalamnya, jadi dalam pembuatan template blog dan web tidak perlu mengetikan seluruh script pembentuknya. Dreamweaver dapat membuat template dengan lebih mudah menggunakan tool-tool di dalamnya.

Aplikasi ini sangat cocok bagi orang yang ingin mempelajari tentang HTML, CSS, PHP, Javascript dan lain-lain. Di versi terbaru Adobe Dreamweaver terdapat perbedaan dalam interface, pembaruan tools, serta posisi dan istilah tool-tool di dalamnya. Salah satu contoh fitur yang dimiliki Dreamweaver adalah fitur browser yang terintegrasi untuk melihat halaman web yang dikembangkan di jendela pratinjau program agar konten memungkinkan untuk terbuka di web browser yang sudah ada.

\section{H. HyperText Markup Language (HTML)}

HTML (HyperText Markup Language) adalah sebuah bahasa markah yang mengkodekan dokumen World Wide Web (WWW) [6]. Ini adalah dokumen-markup dan bahasa spesifikasi-hyperlink yang mendefinisikan sintaks dan penempatan khusus yang tidak ditampilkan secara langsung di web browser namun yang ditampilkan adalah isi dokumen, termasuk teks, gambar, dan media lain yang mendukung. Bahasa ini juga dapat membuat dokumen interaktif melalui hypertext links khusus, yang menghubungkan antara satu dokumen dengan dokumen yang lain pada jaringan. Sintaks dan semantic dari HTML didefinisikan dalam spesifikasi standar HTML. Spesifikasi HTML dan semua masalah standar web yang terkait lainnya dikembangkan di bawah otoritas World Wide Web Consortium (W3C). Spesifikasi HTML terbaru yang disetujui oleh W3C adalah HTML 5.1.

\section{Cascading Style Sheets (CSS)}

CSS (Cascading Style Sheet) dibuat oleh World Wide Web Consortium (W3C) untuk menyelesaikan masalah yang timbul pada dokumen HTML versi 3.2 [7]. Dokumen HTML ini merupakan mimpi buruk untuk para pengembang web karena untuk memberi style pada dokumen HTML para pengembang harus membuat tag-tag tersendiri misalkan tag $<$ font $>$, tag atribut warna $<$ color $>$ dan lain sebagainya pada setiap dokumen HTML yang akhirnya membuat pengembangan web dengan skala besar menjadi lebih kompleks, rumit, dan mahal.

\section{J. Hypertext Preprocessor (PHP)}

PHP (Hypertext Preprocessor) dulu bernama Personal HomePage, pertama kali dibuat oleh Rasmus Lerdof pada tahun 1995 [8]. Fungsi yang paling populer adalah kemampuannya sebagai serverside programming/scripting language dalam pembuatan website, atau aplikasi yang berbasis website. Serverside programming/scripting adalah bahasa yang berjalan pada sisi server (dalam hal ini web server) sehingga komputer client/web browser tidak mengetahui apa yang terjadi didalam web server. Client/web browser hanya menerima keluaran dari proses yang dihasilkan oleh web server. 
K. Interaksi Manusia dan Komputer (IMK)

Interaksi adalah komunikasi antara dua atau lebih objek yang saling mempengaruhi satu sama lain [9]. Interaksi manusia dan komputer merupakan komunikasi dua arah antara pengguna dengan sistem komputer yang saling mendukung untuk mencapai suatu tujuan tertentu.

Ruang lingkup IMK meliputi 3 komponen:

- Manusia: pengguna yang memakai komputer. Pengguna ini berbeda-beda dan memiliki karakteristik masing-masing sesuai dengan kebutuhan dan kemampuannya dalam menggunakan komputer.

- Komputer: Peralatan elektronik yang meliputi perangkat keras (hardware) dan perangkat lunak (software).

- Interaksi: Hubungan antara manusia sebagai pengguna dengan komputer.

\section{HASIL DAN PEMBAHASAN}

Berdasarkan hasil penelitian yang telah dilakukan, maka didapatkan hasil aplikasi toko online pada Toko Winata.

\section{A. Use Case Diagram}

Use case diagram mendeskripsikan sebuah interaksi antara satu atau lebih aktor dengan sistem informasi yang akan dibuat. Use case digunakan untuk mengetahui fungsi apa saja yang ada di dalam sebuah sistem informasi dan siapa saja yang berhak menggunakan fungsi-fungsi tersebut. Setiap use case dilengkapi dengan skenario. Skenario use case adalah alur jalannya proses use case dari sisi aktor dan sistem. Skenario use case dibuat per use case terkecil. Skenario normal adalah skenario jika sistem berjalan normal tanpa terjadi kesalahan atau error. Sedangkan skenario alternatif adalah skenario jika sistem tidak berjalan normal, atau mengalami error. Berikut pada gambar 1 adalah use case diagram untuk aplikasi yang akan dirancang.

Pada use case diagram aplikasi ini diberikan gambaran singkat mengenai apa saja yang dapat dilakukan oleh pengguna aplikasi, dalam hal ini konsumen, guest/tamu seta pemilik dan pegawai toko Winata yang diwakilkan dengan simbol actor admin gudang dan admin toko. Use case utama dari ketiga aktor, baik itu konsumen, admin Gudang serta admin toko adalah login, sebelum dapat melakukan aktivitas lainnya. Sedangkan pada aktor guest/tamu tidak perlu melakukan login pada sistem, akan tetapi memiliki keterbatasan akses konten pada situs web yang dibuat.
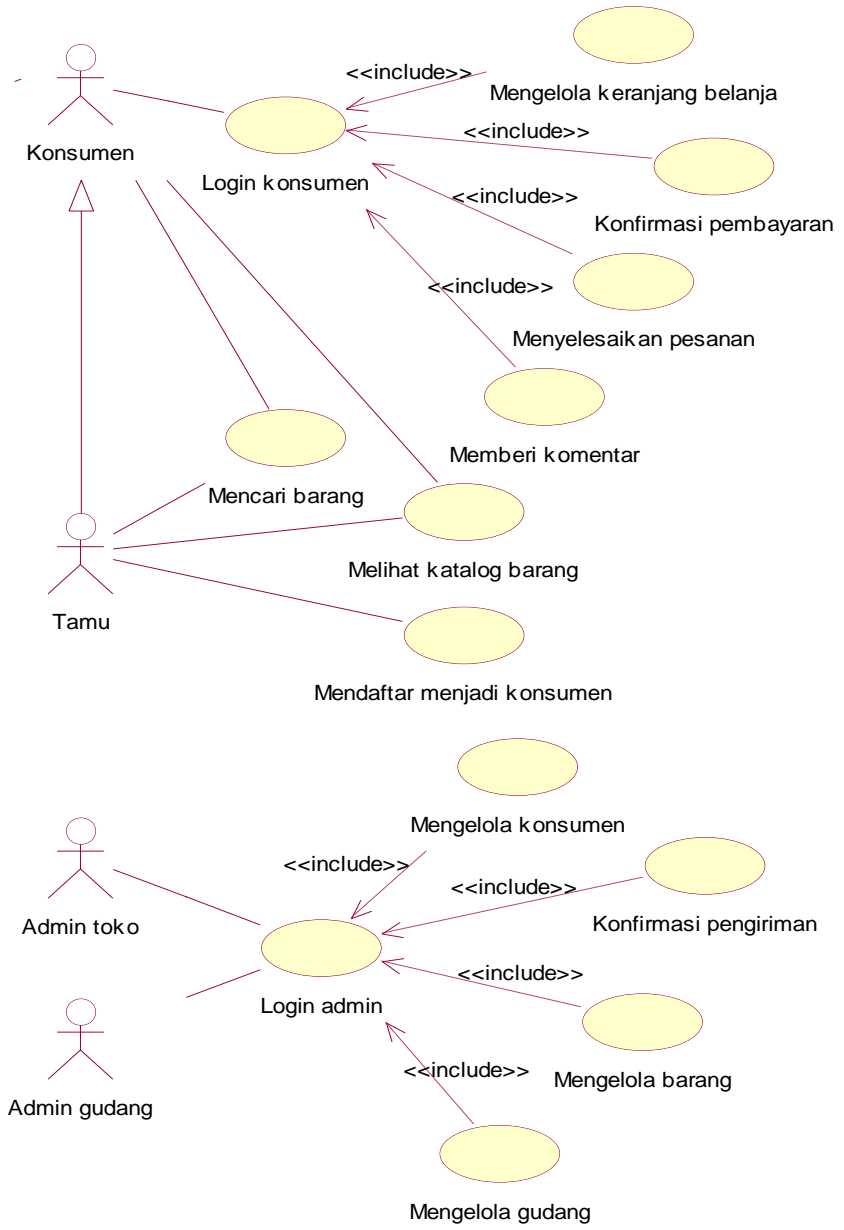

Gambar 1. Use Case Diagram Aplikasi Toko Online

\section{B. Activity Diagram}

Diagram aktivitas atau activity diagram menggambarkan aliran kerja atau aktivitas dari sebuah sistem atau proses bisnis atau menu yang ada pada perangkat lunak. Diagram aktivitas juga merupakan rancangan proses bisnis dimana setiap urutan aktivitas yang digambarkan merupakan proses bisnis sistem yang didefinisikan. Berikut ini adalah diagram aktivitas untuk aplikasi yang dirancang:

- Diagram Aktivitas Pendaftaran Konsumen

Pada diagram aktivitas di gambar 2, tamu memasukkan email, kata sandi, dan data konsumen. Sistem memeriksa apakah email sudah digunakan. Jika sudah digunakan maka sistem memberikan peringatan dan tamu diberikan kesempatan untuk mengganti email. Jika belum digunakan sistem menyimpan data konsumen baru ke database. Setelah itu sistem mengirimkan email verifikasi dan tamu merespon dengan melakukan verifikasi melalui email. Setelah email terverifikasi maka sistem mengubah status konsumen menjadi aktif. 


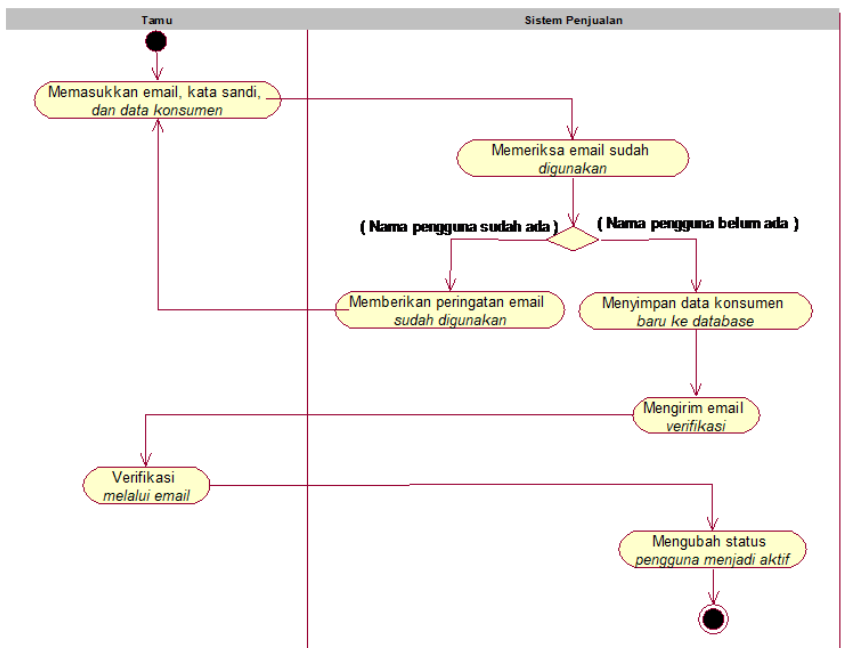

Gambar 2. Activity Diagram Pendaftaran Konsumen

- Diagram Aktivitas Pengelolaan Keranjang Belanja

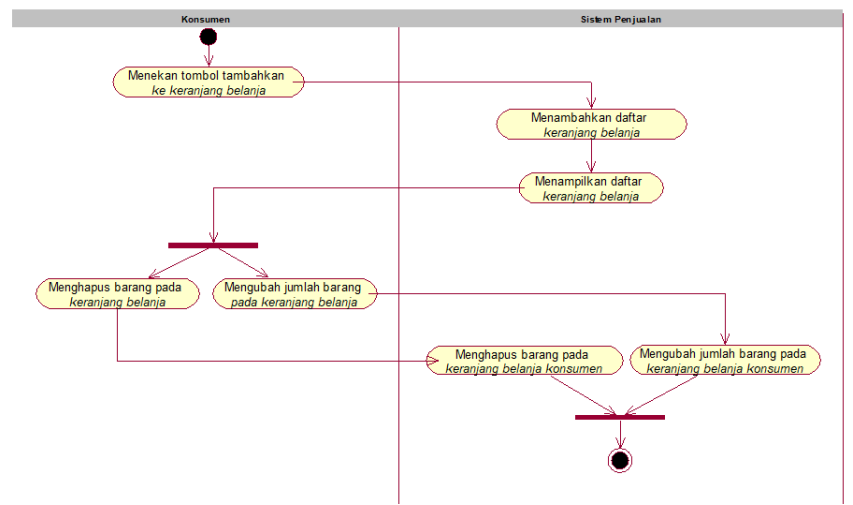

Gambar 3. Activity Diagram Pengelolaan Keranjang Belanja

Pada gambar 3 diatas, konsumen menekan tombol tambahkan ke keranjang belanja. Sistem menambahkan dan menampilkan daftar keranjang belanja. Konsumen dapat mengubah atau menghapus barang pada keranjang belanja. Jika konsumen mengubah maka sistem merespon dengan mengubah jumlah keranjang belanja konsumen. Jika konsumen menghapus barang maka sistem merespon dengan menghapus barang pada keranjang belanja.

- Diagram Aktivitas Penyelesaian Pesanan

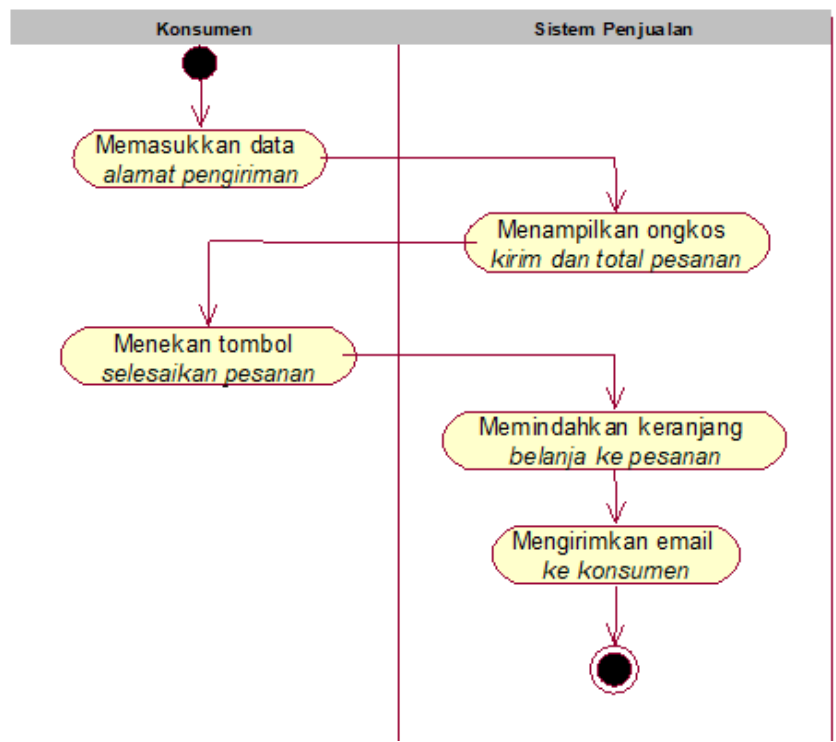

Gambar 4. Activity Diagram Penyelesaian Pesanan

Pada gambar 4 diatas konsumen memasukkan alamat pengiriman dan sistem merespon dengan menampilkan ongkos kirim dan total pesanan. Kemudian konsumen menekan tombol selesaikan pesanan. Sistem memindahkan keranjang belanja ke pesanan dan mengirimkan email kepada konsumen.

- Diagram Aktivitas Konfirmasi Pembayaran

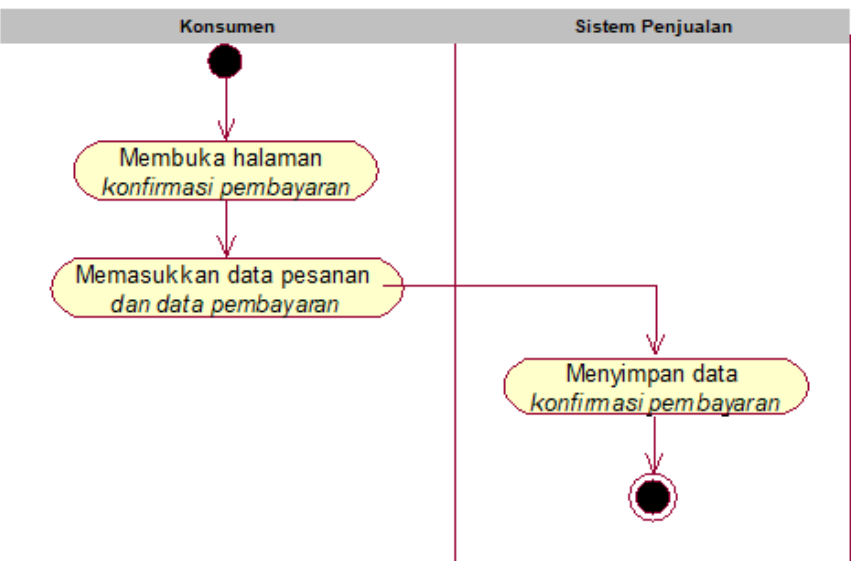

Gambar 5. Activity Diagram Konfirmasi Pembayaran

Pada gambar 5 diatas konsumen yang sudah menyelesaikan pembayaran membuka halaman konfirmasi pembayaran kemudian memasukkan data pesanan dan data pembayaran. Sistem merespon dengan menyimpan data konfirmasi pembayaran.

- Diagram Aktivitas Konfirmasi Pengiriman 


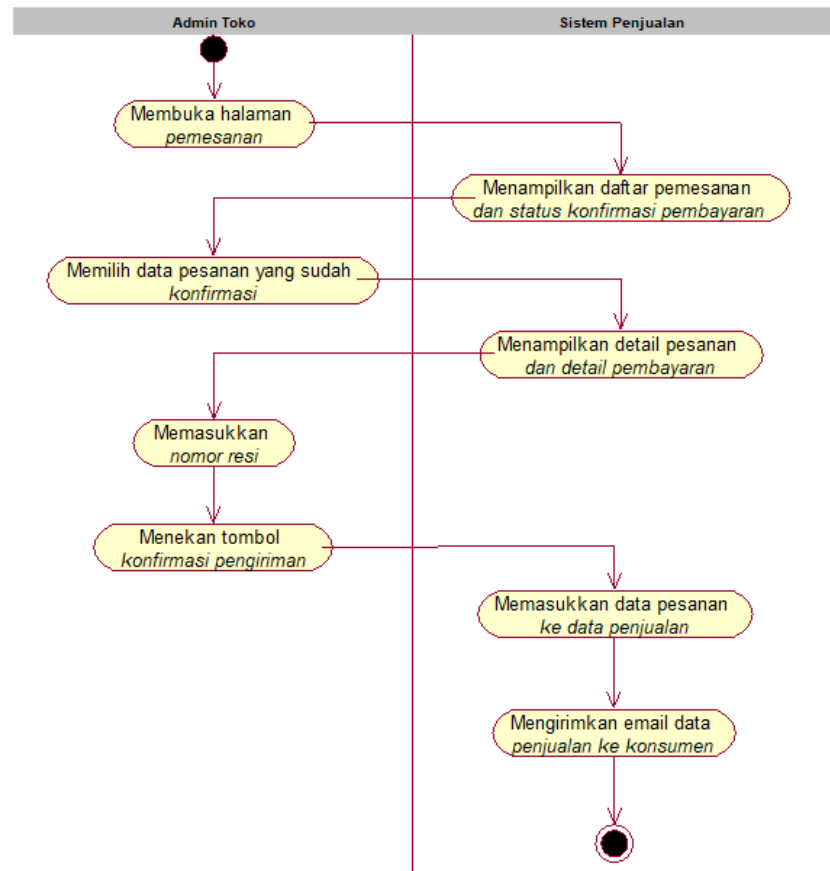

Gambar 6. Activity Diagram Konfirmasi Pengiriman

Pada gambar 6, administrator toko membuka halaman pemesanan dan sistem merespon dengan menampilkan daftar pemesanan dan status konfirmasi pembayaran.
Kemudian administrator toko memilih data pesanan yang sudah melakukan konfirmasi. Setelah itu sistem menampilkan detail pesanan dan detail pembayaran. Administrator toko memasukkan nomor resi dan menekan tombol konfirmasi pengiriman. Sistem merespon dengan memasukkan data pesanan ke data penjualan kemudian mengirimkan email data penjualan ke konsumen.

\section{Conceptual Data Model (CDM)}

Pada gambar 7 akan menampilkan Conceptual Data Model (CDM) dari sistem informasi toko online ini. CDM adalah model data yang diperlukan oleh sistem secara konseptual yang berkaitan dengan pandangan pengguna terhadap data yang disimpan dalam basis data. CDM dibuat sudah dalam bentuk tabel-tabel tanpa tipe data yang menggambarkan relasi antar tabel yang berguna untuk keperluan implementasi ke basis data.

D. Physical Data Model

Physical Data Model (PDM) yang terdapat pada gambar 8 adalah model data yang menggunakan beberapa tabel untuk menggambarkan data beserta hubungan antar data. Setiap tabel mempunyai sejumlah kolom di mana setiap kolom memiliki nama yang unik beserta tipe datanya. PDM merupakan konsep yang menerangkan detail dari bagaimana data di simpan di dalam basis data.

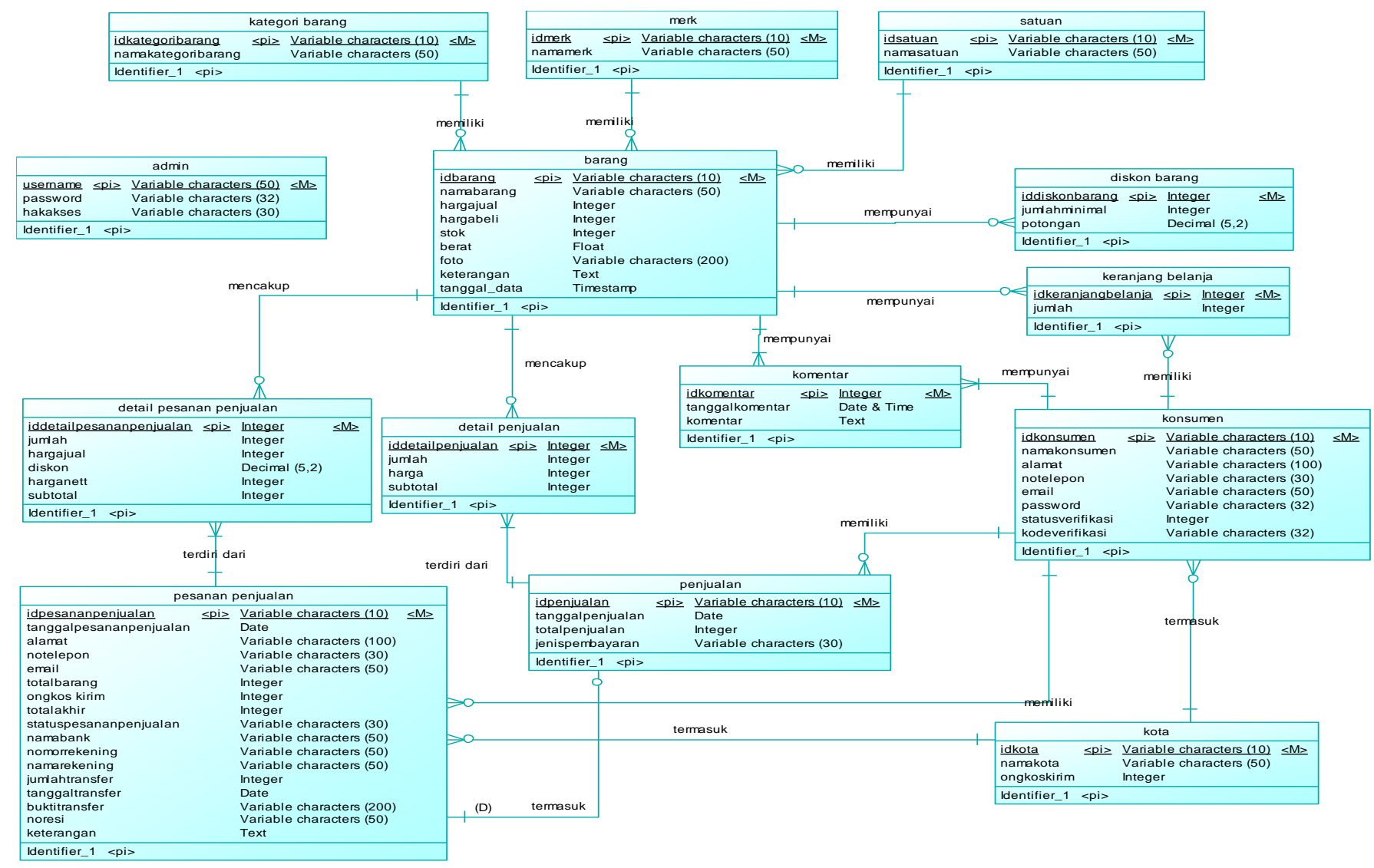

Gambar 7. Conceptual Data Model Toko Online 


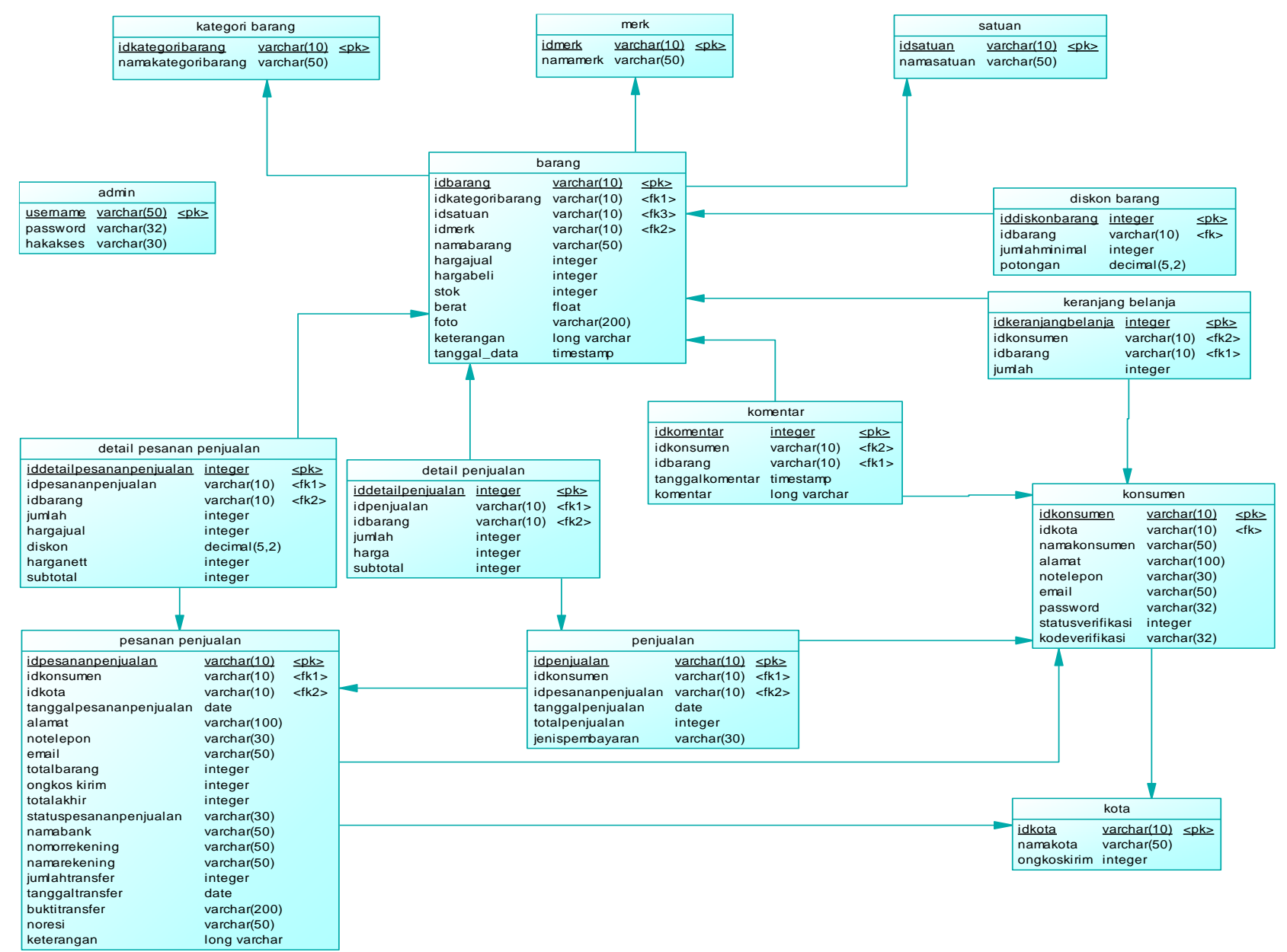

Gambar 8. Physical Data Model Toko Online

\section{E. Interaction Flow Modeling Language (IFML)}

Interaction flow modeling language (IFML) adalah bahasa pemodelan yang sangat terinspirasi oleh WebML dan mewakili generalisasi dari domain web untuk aplikasi generic pemodelan front-end. IFML dirancang untuk mengekspresikan konten, interaksi pengguna, dan mengatur perilaku dari front-end aplikasi perangkat lunak. Salah satu perangkat lunak yang mendukung dalam pembuatan IFML adalah eclipse dengan memberikan plugin yang didapat dari website http://ifml.github.io/. Kelebihan dalam penggunaan IFML salah satunya adalah mempermudah komunikasi desain interaksi kepada pemangku kepentingan non-teknis. Berikut ini adalah IFML untuk aplikasi yang akan dirancang:

- IFML Pendaftaran Konsumen

Pada gambar 9 dapat dilihat tamu yang ingin mendaftar menjadi konsumen harus mengisi data pada halaman pendaftaran konsumen dan menekan tombol daftar. Setelah mengisi, hasil input tamu masuk ke dalam sistem untuk dilakukan pengecekan apakah tipe data sesuai dan email belum digunakan. Jika ada tipe data yang tidak sesuai atau email sudah digunakan, maka akan kembali ke halaman pendaftaran dan tamu harus memperbaiki input atau mengganti email. Tetapi jika tipe data sudah sesuai dan email belum digunakan maka akan muncul notifikasi pendaftaran perlu dikonfirmasi dan sistem akan mengirimkan email konfirmasi yang harus diverifikasi oleh tamu. Ketika tamu sudah memverifikasi melalui email maka akan muncul notifikasi verifikasi sukses dan sistem akan menyimpan verifikasi dan mengubah status konsumen menjadi aktif.

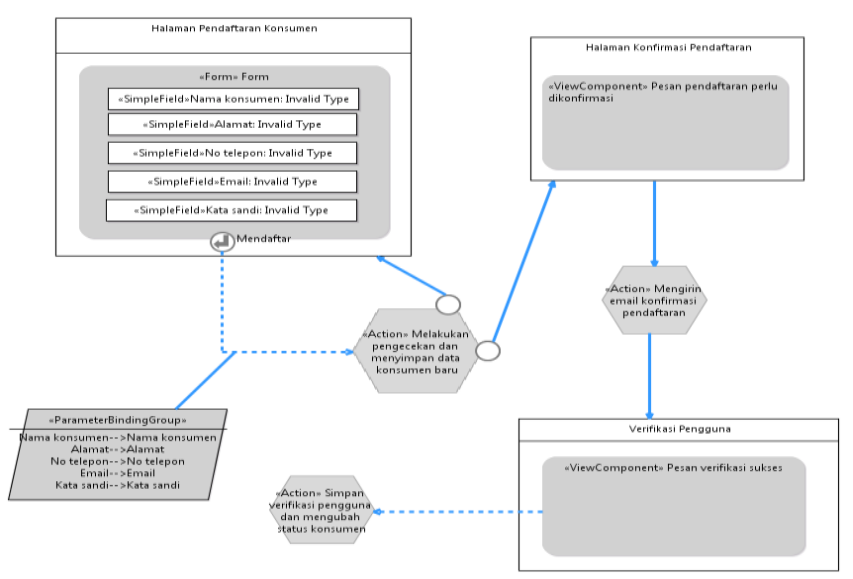

Gambar 9. IFML Pendaftaran Konsumen 
- IFML Pengelolaan Keranjang Belanja

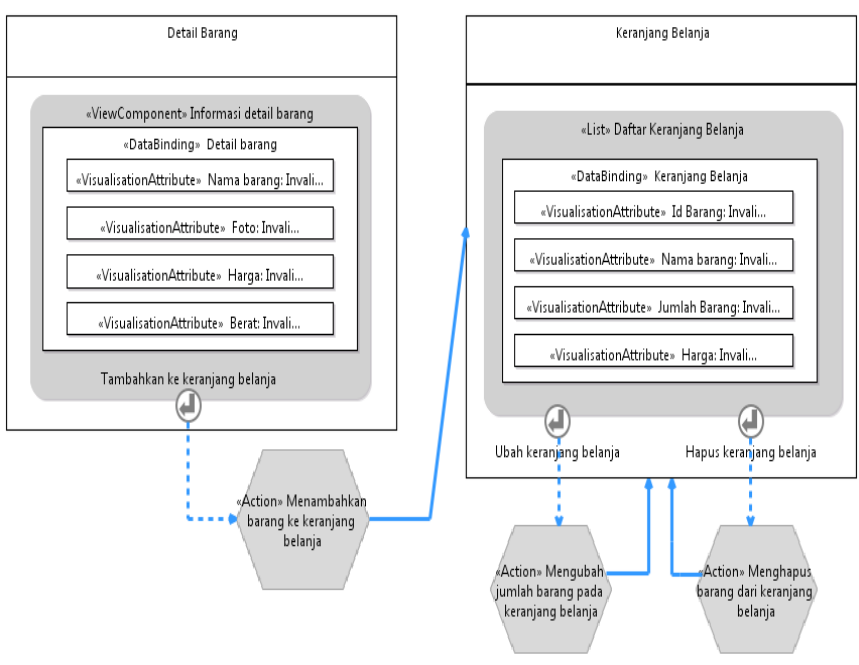

Gambar 19. IFML Pengelolaan Keranjang Belanja

Pada gambar 10 di atas konsumen yang ingin melakukan pembelian harus menekan tombol tambahkan ke keranjang belanja pada halaman detail barang kemudian sistem menambahkan barang pada keranjang belanja. Pada keranjang belanja konsumen dapat mengubah atau menghapus barang. Jika konsumen memilih untuk mengubah barang maka sistem akan mengubah jumlah barang pada keranjang belanja. Jika konsumen memilih untuk menghapus barang maka sistem akan menghapus barang dari keranjang belanja.

- IFML Penyelesaian Pesanan

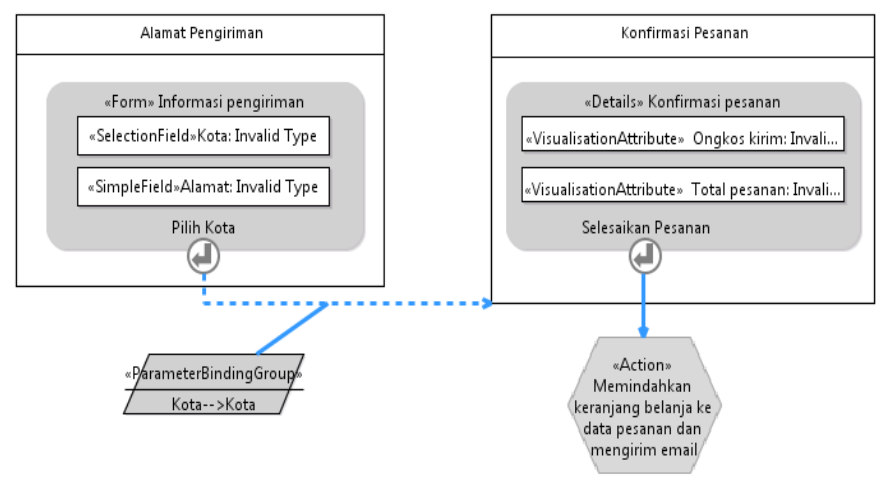

Gambar 11. IFML Penyelesaian Pesanan

Pada gambar 11 di atas konsumen memilih kota dan alamat pengiriman kemudian sistem mengirim hasil input dan menampilkan konfirmasi pesanan yang berisi ongkos kirim dan total pesanan. Konsumen menyelesaikan pesanan dan sistem memindahkan data keranjang belanja ke pesanan penjualan dan mengirimkan email ke konsumen.

- IFML Konfirmasi Pembayaran

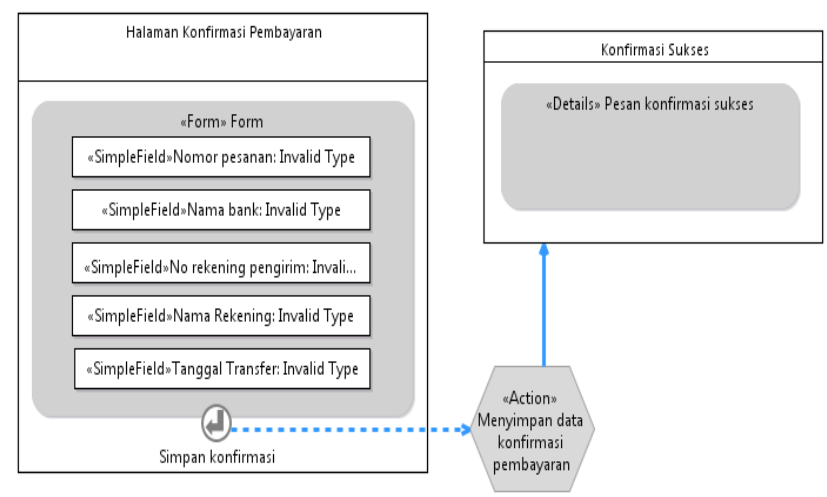

Gambar 12. IFML Konfirmasi Pembayaran

Pada gambar 12 di atas konsumen mengisi form pada halaman konfirmasi pembayaran. Setelah itu sistem menyimpan data konfirmasi pembayaran dan menampilkan notifikasi konfirmasi sukses.

- IFML Konfirmasi Pengiriman

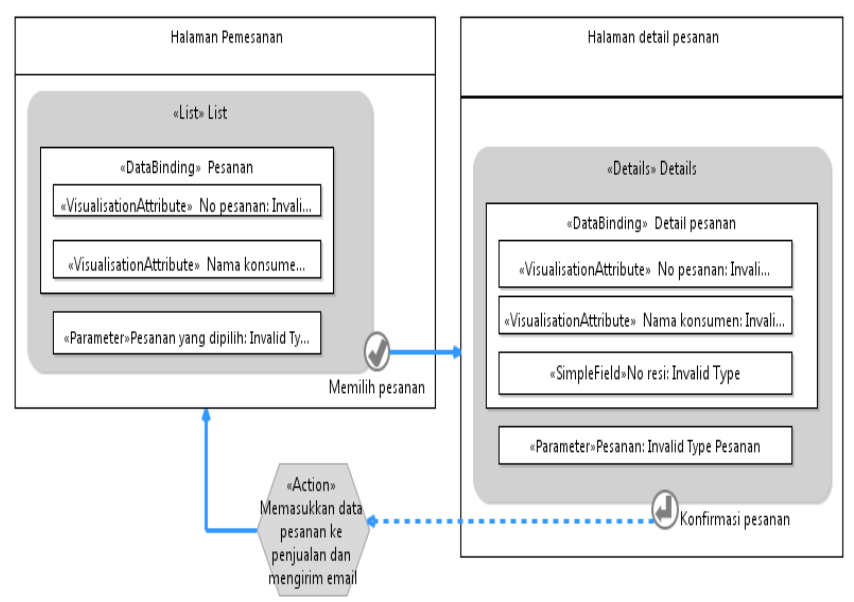

Gambar 13. IFML Konfirmasi Pengiriman

Pada gambar 13 di atas halaman pemesanan menampilkan data pesanan dan administrator toko memilih salah satu pesanan. Parameter yang digunakan untuk membuka halaman detail pesanan adalah pesanan yang dipilih administrator toko. Kemudian sistem menampilkan halaman detail pesanan dan memasukkan no resi pengiriman. Setelah itu sistem memasukkan data pesanan ke penjualan dan mengirim email ke konsumen.

F. Desain Antar Muka

Pada sub bab ini akan dijelaskan tentang tampilan antar muka dari toko online yang akan berinteraksi langsung dengan pengguna.

- Antar Muka Beranda

Antar muka beranda merupakan menu awal yang tampil dan pengguna dapat melihat semua pilihan menu yang terdapat dalam website. Pada menu beranda terdapat slideshow gambar Toko Winata, barang terbaru, dan 
barang terlaris. Di bagian samping terdapat kategori dan merk barang. Berikut ini gambar antar muka menu beranda:

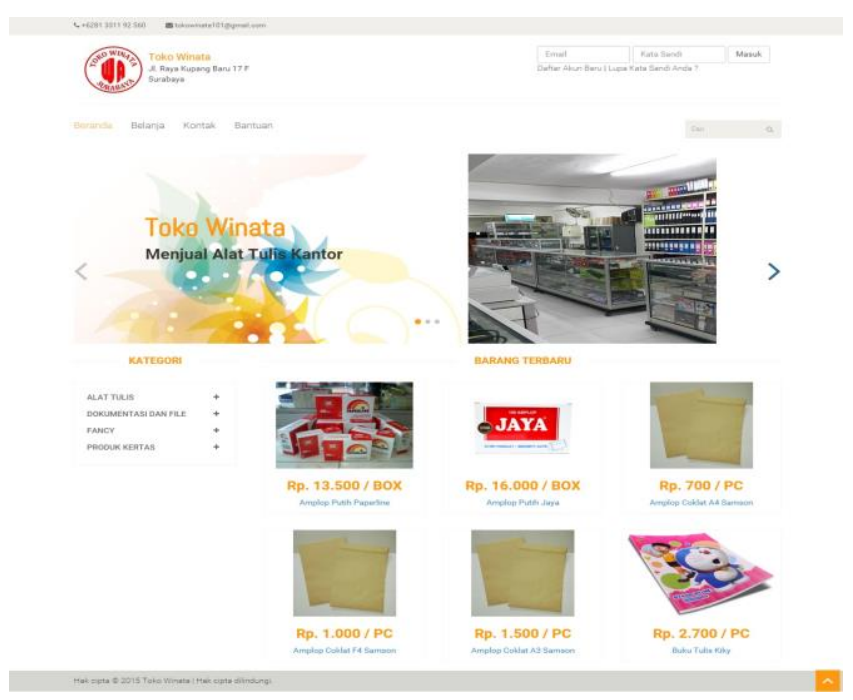

Gambar 14. Halaman Beranda

- Antar Muka Daftar Konsumen

Antar muka daftar konsumen merupakan tampilan yang berisi textbox data konsumen yang harus diisi tamu jika ingin menjadi konsumen dan melakukan transaksi dalam website ini. Berikut ini gambar antar muka daftar konsumen:

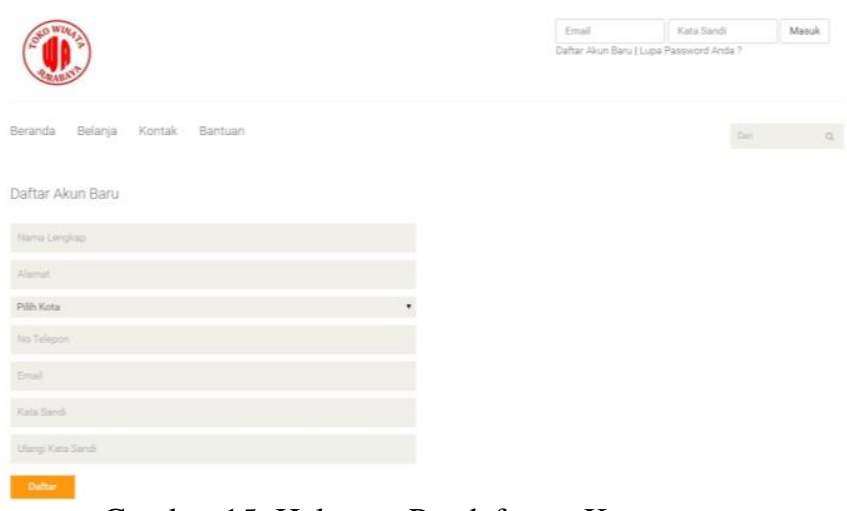

Gambar 15. Halaman Pendaftaran Konsumen.

- Antar Muka Detail Barang

Antar muka detail barang merupakan tampilan yang berisi harga barang, tombol tambah keranjang belanja, ketersediaan, kategori, merk, dan keterangan barang. Antar muka ini dapat diakses tamu/konsumen namun terdapat perbedaan pada fitur yang dapat digunakan. Jika pengguna sudah melakukan login maka akan tersedia tombol tambah keranjang belanja yang dapat digunakan untuk menambahkan barang yang ingin dibeli ke dalam keranjang belanja. Jika pengguna belum melakukan login maka tombol tambah keranjang belanja tidak tersedia. Berikut ini gambar antar muka detail barang:

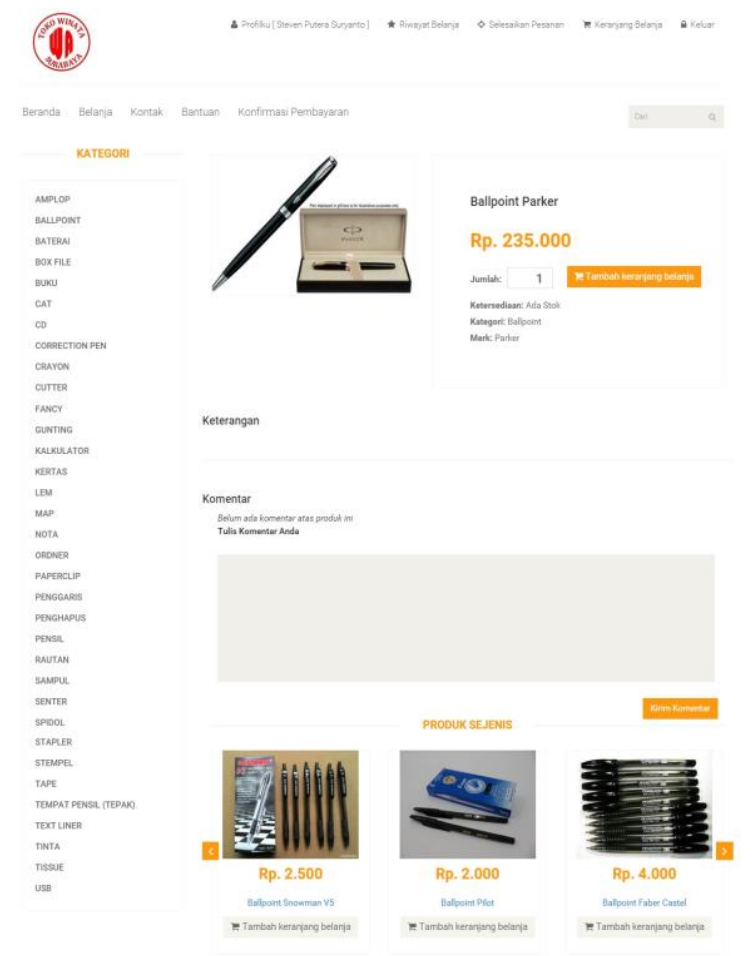

Gambar 16. Halaman Detail Barang

- Antar Muka Keranjang Belanja

Antar muka keranjang belanja merupakan tampilan yang berisi barang yang hendak dibeli oleh konsumen. Pada antar muka ini juga terdapat gambar, nama, harga, dan jumlah barang serta subtotal dan total keseluruan. Antar muka keranjang belanja hanya dapat diakses oleh konsumen. Dalam antar muka ini konsumen dapat merubah jumlah/ menghapus barang. Terdapat 2 tombol dalam antar muka ini yaitu tombol kembali berbelanja yang akan mengembalikan konsumen ke antar muka katalog barang dan tombol selesaikan pesanan jika konsumen sudah selesai berbelanja. Berikut ini gambar antar muka keranjang belanja:
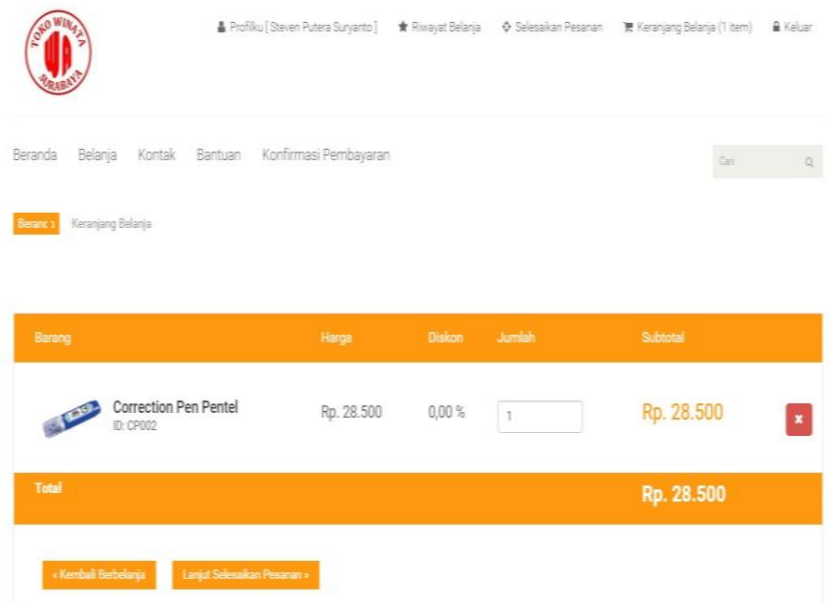

Gambar 17. Halaman Keranjang Belanja 
- Antar Muka Penyelesaian Pesanan

Antar muka selesaikan pesanan merupakan tampilan yang berisi data barang yang terdapat pada keranjang belanja dan data pengiriman barang yang diisi konsumen dimana dapat mempengaruhi jumlah yang harus dibayarkan konsumen karena terdapat ongkos kirim yang disesuaikan dengan alamat konsumen. Antar muka ini hanya dapat diakses oleh konsumen. Berikut ini gambar antar muka selesaikan pesanan:

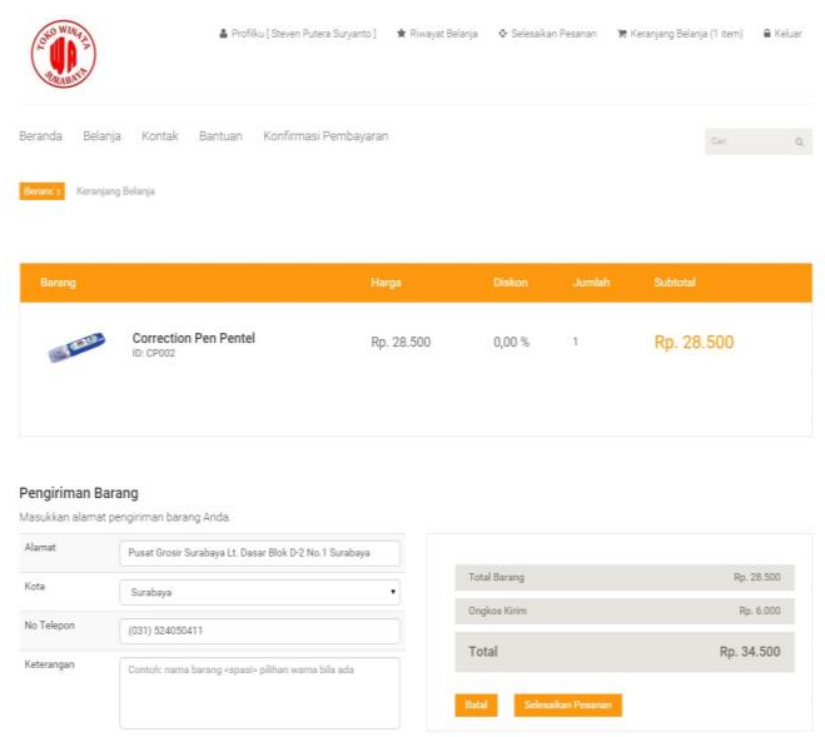

Gambar 18. Halaman Penyelesaian Pesanan

- Antar Muka Pesanan Penjualan

Antar muka pesanan penjualan merupakan tampilan data pesanan penjualan yang hanya dapat diakses administrator. Pada antar muka ini administrator dapat melihat detail pesanan penjualan dan juga terdapat tombol pengiriman barang jika konsumen sudah selesai melakukan konfirmasi pembayaran. Terdapat beberapa status pesanan yaitu "belum konfirmasi" yang berarti konsumen sudah melakukan menyelesaikan pesanan namun belum melakukan konfirmasi pembayaran, "sudah konfirmasi” jika konsumen sudah melakukan konfirmasi pembayaran, "sudah terkirim" jika administrator sudah memasukkan nomor resi pengiriman barang, dan "kadaluwarsa" jika dalam waktu 3 hari dari penyelesaian pesanan tidak dilakukan konfirmasi pembayaran. Berikut ini gambar antar muka pesanan penjualan:

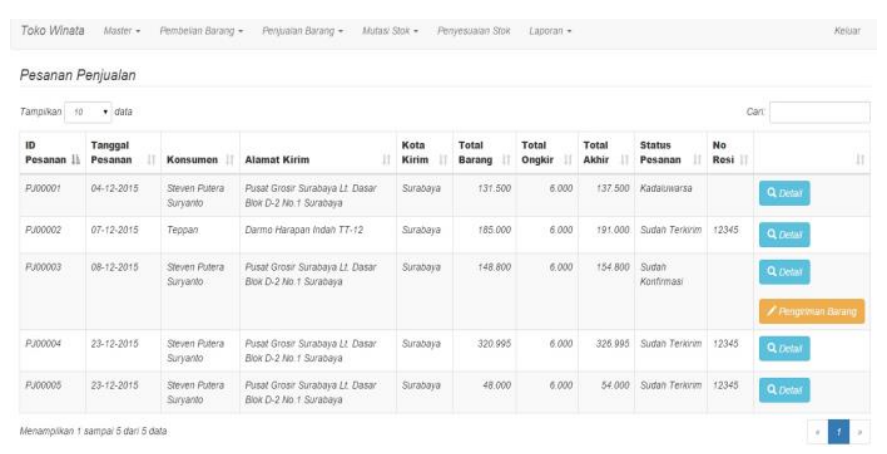

Gambar 19. Halaman Pesanan Penjualan

\section{- Antar Muka Konfirmasi Pembayaran}

Antar muka konfirmasi pembayaran merupakan tampilan yang berisi textbox data konfirmasi pembayaran yang dapat diisi oleh konsumen. Dalam antar muka ini konsumen juga dapat melakukan upload bukti transfer yang dapat membantu administrator untuk lebih mudah dalam melakukan pengecekan. Berikut ini gambar antar muka konfirmasi pembayaran:

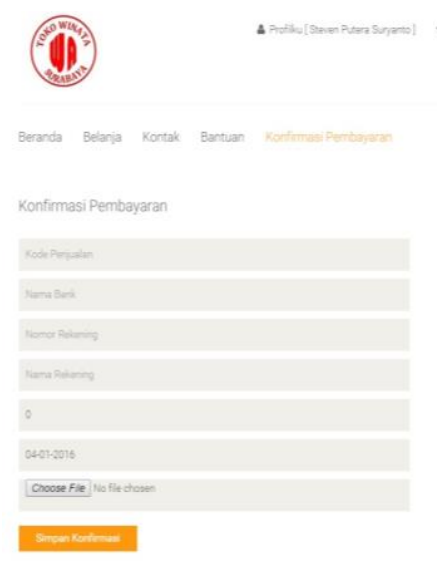

Gambar 20. Halaman Konfirmasi Pembayaran

- Antar Muka Konfirmasi Pengiriman

Antar muka konfirmasi pengiriman merupakan tampilan data pesanan penjualan dan detail pesanan yang hanya dapat diakses oleh administrator. Dalam antar muka ini administrator dapat memasukkan nomor resi pengiriman barang dan menekan tombol simpan pengiriman yang merubah pesanan penjualan menjadi penjualan. Berikut antar muka konfirmasi pengiriman:

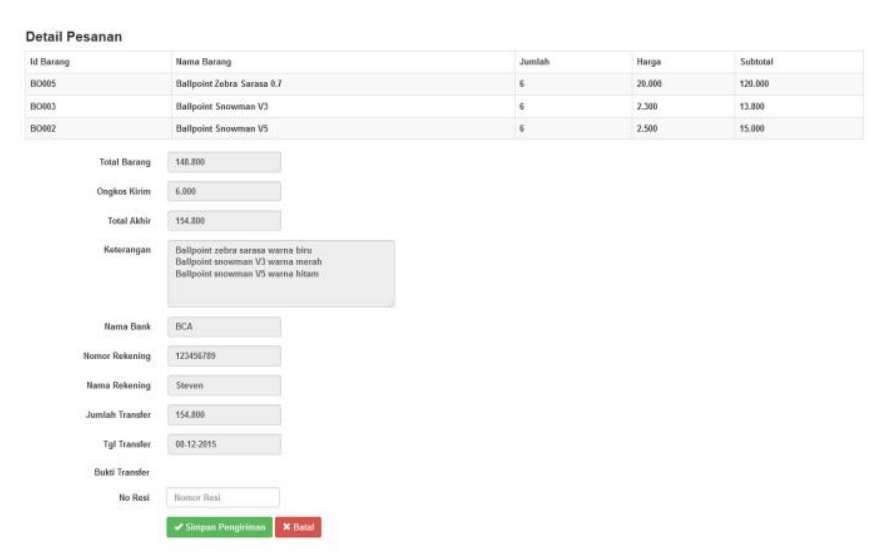

Gambar 21. Halaman Konfirmasi Pengiriman

\section{G. Pengujian}

Pada bagian ini akan dijelaskan mengenai uji coba terhadap toko online pada Toko Winata yang telah dibuat. Uji coba yang dilakukan dimulai dari proses pendaftaran konsumen, pembelian barang, konfirmasi pembayaran, konfirmasi pengiriman melalui administrator. Metode yang 
digunakan dalam uji coba aplikasi menggunakan metode basis path yang merupakan bagian dari white box testing.

\section{a) Uji Coba Proses Pemesanan Barang}

Uji coba proses pemesanan barang dilakukan pada saat konsumen memasukkan barang ke dalam keranjang belanja dan menyelesaikan pesanan. Halaman keranjang belanja akan diambil untuk melakukan pengujian basis path, dimana halaman tersebut terdapat fitur untuk menyelesaikan pesanan dan menyimpan data pesanan penjualan. Berikut flowgraph dari basis path halaman keranjang belanja:
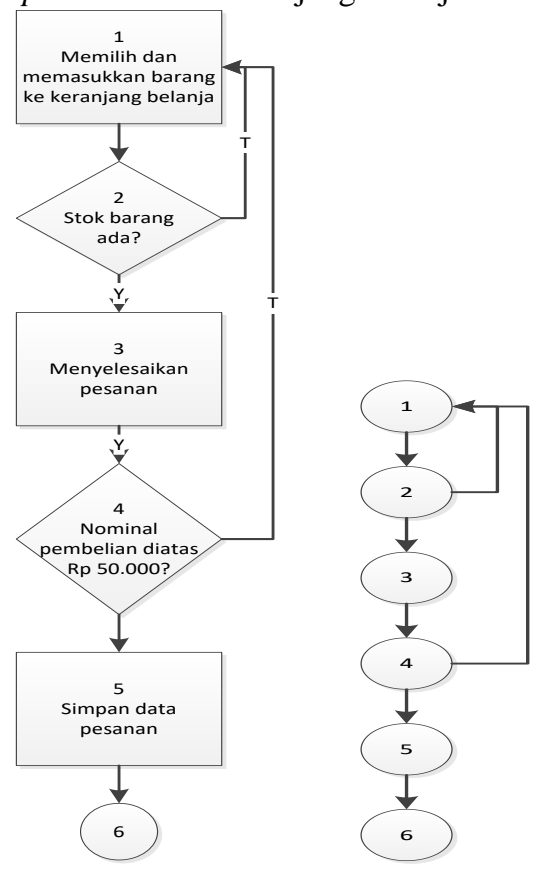

Gambar 22. Flowgraph Halaman Belanja

Dari gambar 20, didapat jumlah titik (node) dan jumlah garis (edge) adalah 6 node dan 7 edge. Maka, nilai kompleksitas siklomatik akan dijelaskan sebagai berikut:

$$
\begin{aligned}
& \text { Jumlah edge }=7 \text { dan jumlah node }=6 \\
& =7-6+2 \\
& =3
\end{aligned}
$$

Didapat nilai kompleksitas siklomatik pada flowgraph proses pemesanan barang adalah 3 sehingga terbentuk 3 jalur independen (independent path) yang dapat dilihat sebagai berikut:

Tabel 2. Hasil Independent Path Halaman Belanja

\begin{tabular}{cll}
\hline Jalur & \multicolumn{1}{c}{ Path } & \multicolumn{1}{c}{ Keterangan } \\
\hline A. & $1-2-3-4-5-6$ & Berhasil memesan barang \\
\hline B. & $1-2$ & $\begin{array}{l}\text { Tidak berhasil memesan } \\
\text { barang }\end{array}$ \\
\hline C. & $1-2-3-4$ & $\begin{array}{l}\text { Tidak berhasil memesan } \\
\text { barang }\end{array}$ \\
\hline
\end{tabular}

b) Uji Coba Master Barang

Menu master barang akan diambil untuk pengujian basis path, dimana menu master barang dapat mewakili menu master lainnya dalam sistem secara keseluruhan. Berikut flowgraph dari basis path menu master barang:

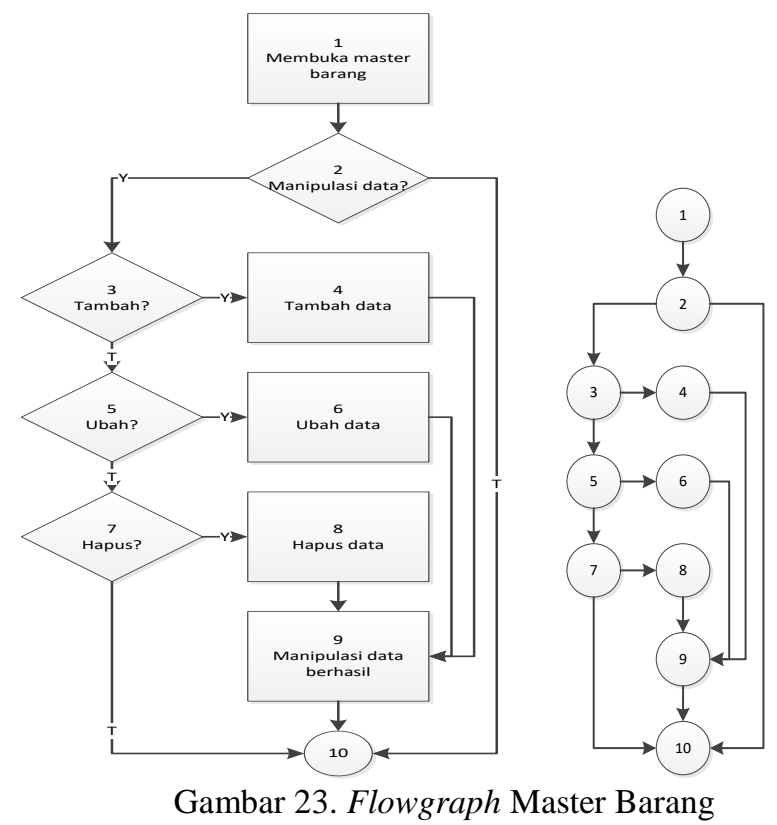

Dari gambar di atas didapat jumlah titik (node) dan jumlah garis (edge) adalah 10 node dan 13 edge. Maka, nilai kompleksitas siklomatik akan dijelaskan sebagai berikut:

$$
\begin{aligned}
& \text { Jumlah } e d g e=13 \text { dan jumlah node }=10 \\
& =13-10+2 \\
& =5
\end{aligned}
$$

Didapat nilai kompleksitas siklomatik pada flowgraph master barang adalah 5 sehingga terbentuk 5 jalur independen (independent path) yang dapat dilihat sebagai berikut:

Tabel 3. Hasil Independent Path Master Barang

\begin{tabular}{ccl}
\hline Jalur & \multicolumn{1}{c}{ Path } & \multicolumn{1}{c}{ Keterangan } \\
\hline 1. & $1-2-3-4-9-10$ & $\begin{array}{l}\text { Berhasil memanipulasi data } \\
\text { barang }\end{array}$ \\
\hline 2. & $1-2-3-5-6-9-10$ & $\begin{array}{l}\text { Berhasil memanipulasi data } \\
\text { barang }\end{array}$ \\
\hline 3. & $1-2-3-5-7-8-9-10$ & $\begin{array}{l}\text { Berhasil memanipulasi data } \\
\text { barang }\end{array}$ \\
\hline 4. & $1-2-3-5-7-10$ & $\begin{array}{l}\text { Tidak berhasil memanipulasi } \\
\text { data barang }\end{array}$ \\
\hline 5. & $1-2-10$ & $\begin{array}{l}\text { Tidak berhasil memanipulasi } \\
\text { data barang }\end{array}$ \\
\hline
\end{tabular}

\section{KESIMPULAN DAN SARAN}

A. Kesimpulan

Dalam pembuatan aplikasi toko online pada Toko Winata penulis dapat mengambil beberapa kesimpulan, antara lain: 
- Untuk merancang dan mendesain website e-commerce sebagai media transaksi penjualan online Toko Winata yang user-friendly, penulis mengerjakan aplikasi ini dengan membandingkan pada aplikasi toko online yang menjual alat tulis kantor (ATK) lainnya untuk menemukan rancangan yang sesuai agar memudahkan konsumen dalam melakukan transaksi.

- Aplikasi yang dikembangkan dapat memasarkan dan memberikan informasi barang Toko Winata yang terbaru dan lengkap kepada konsumen dengan cara menyediakan fitur barang terbaru yang terdapat pada halaman beranda toko online ini.

B. Saran

Penulis menyadari bahwa aplikasi ini masih jauh dari kesempurnaan. Oleh karena itu penulis memberikan saransaran yang berguna dalam pengembangan sistem lebih lanjut yaitu:

- Aplikasi toko online pada Toko Winata dapat dikembangkan lebih lanjut dengan menambahkan fitur tracking untuk memudahkan konsumen dalam memantau barang dan memberikan pilihan pengiriman cepat agar memudahkan konsumen yang ingin menerima barang lebih cepat.

- Aplikasi toko online pada Toko Winata dapat dikembangkan lebih lanjut dengan menambahkan fitur pembayaran menggunakan kartu kredit sehingga konsumen dapat lebih mudah dan praktis dalam melakukan transaksi.
- Aplikasi toko online pada Toko Winata dapat dikembangkan lebih lanjut dengan menambahkan fitur membandingkan barang sehingga dapat membantu konsumen untuk melihat perbedaan barang dan membeli barang yang diinginkan.

\section{REFERENSI}

[1] Rosa, A S dan Shalahuddin, M. (2013). Rekayasa Perangkat Lunak: Terstruktur dan Berorientasi Objek. Bandung: Informatika.

[2] Kalakota, R. dan Whinston, A.B. (1997). Electronic Commerce: a Manager's Guide. Amerika Serikat: Addison-Wesley.

[3] http://www.ifml.org/, Diakses pada tanggal 27 Agustus 2015, 13.00 WIB.

[4] https://upyes.wordpress.com/2013/02/06/pengertiandan-sejarah-mysq1/, Diakses pada tanggal 25 Agustus 2015, 13.05 WIB.

[5] http://regibrader-free.blogspot.com/2014/09/downloadadobe-dreamweaver-cs3-full-crack.html, Diakses pada tanggal 30 Agustus 2015, 18.10 WIB.

[6] Spainhour, S. dan Eckstein, R. (2003). Webmaster in a Nutshell (3 rd ed.). Amerika Serikat: O'Reilly.

[7] http://www.w3function.com/blog/index.php?p=det\&idn $=31$, Diakses pada tanggal 25 Agustus 2015, 15.00 WIB.

[8] http://www.academia.edu/4603746/Pengertian_PHP_M y_SQL, Diakses pada tanggal 24 Agustus 2015, $2 \overline{1} .00$ WIB.

[9] Santosa, I. (2006). Interaksi Manusia dan Komputer: Teori dan Praktek edisi 2. Yogyakarta: Andi. 